\title{
GAMIFICATION IN EDUCATION AND ACTIVE METHODOLOGIES AT HIGHER EDUCATION
}

\author{
A.P. Lopes ${ }^{1}$, M. Soler ${ }^{2}$, R. Caña², L. Cortés ${ }^{2}$, M. Bentabol², A. Bentabol' \\ M.M. Muñoz ${ }^{2}$, A. Esteban², M.J. Luna² \\ ${ }^{1}$ CEOS.PP / ISCAP / Polytechnic of Porto (PORTUGAL) \\ ${ }^{2}$ University of Malaga (SPAIN)
}

\begin{abstract}
In recent years, there has been an increasing interest in applying Gamification in Education, which can be defined as the application of game design elements to learning activities. Its purpose is to motivate students by creating an engaging learning experience that can keep students focused on the learning task and its application in the classroom, is still in its emergent stages. Gamification is a great challenge for education, particularly in Higher Education Institutions (HEI) in such a traditional context, as is the case with courses like Management and Administration Business, Finance and Accounting, Marketing and Market Research, Chemistry, Accounting and Administration and Business Communication.
\end{abstract}

This paper presents a study, applied in the 2016/2017 and 2017/2018 academic years, in which the teaching method focuses on a blended learning approach, through the implementation of a flipped classroom model and also through the introduction of online gamification activities such Kahoot! application. Kahoot is a game-based learning platform, used as educational technology that can easily be used for initial, formative and summative assessment of students' knowledge using individual or collaborative team work mode, adding vitality, student engagement, and also meta-cognitive supports to higher education classrooms with limited instructor or student training required. The participants, in the study, were about 3000 students of 17 different subjects from the aforementioned courses, of the Malaga University and Polytechnic of Porto.

The results of this study suggest that this model improves student learning and are of relevance to researchers, educators and game-based learning designers.

Keywords: Engagement, Flipped Learning, Higher Education, Gamification in Education, Kahoot, Active Learning.

\section{INTRODUCTION}

In recent times, the "Flipped Classroom" has obtained much attention and acceptance in Higher Education Institutions (HEI). This new model for organizing the educational process is a pedagogical inversion of the traditional teaching paradigm: the main elements of the usual classroom teaching and learning process are now prepared by students before they come to class, so that they can engage with that content at a deeper level in the classroom ([1], [2]).

The flipped classroom model is based on a set of theories, including constructivism, active learning, and peer-assisted learning [3]. This pedagogical approach may incorporate a large array of out-ofclass activities, and in-class activities may include a wide range of approaches, such as role-play, debates, quizzes, and group presentations, amongst many others [4]. In the flipped classroom, the instructor becomes a kind of guide and facilitator, indicating the way to go while taking care not to lead the way, motivating students in their own knowledge construction, letting them lead the way, following and supporting, and constantly and carefully monitoring their learning outcomes [5]. The instructor should try to use multiple approaches as opposed to a single model; these may include group discussion, mini-lectures for review, and gamification [6].

Gamification is a relatively new concept and refers to the "use of elements of game design in contexts not related to games" ([7], [8]). It can be applied in very different areas, such as education and business. "Gamification is using game-based mechanics, aesthetics and game thinking to engage people, motivate action, promote learning, and solve problems" [9]. The crucial aim of gamification applied to education is to increase the motivation of the student to achieve a certain goal through the addition to the learning system of components related to the mechanics of games. Gamification should also lead to a change in student behaviour [10]. 
Gamification in education has in fact been shown to increase students' motivation for learning [11]. The concept is of particular interest because younger students have been surrounded by entertainment technology for all their lives [12].

Nevertheless, the use of gamification in education should go beyond the issue of motivation, because it has the capacity to overcome student inactivity, as well as lack of understanding or difficulty, through greater student involvement. Zichermann and Cunningham [13] identified the important elements of games (points, levels, progression, etc.) to apply in gamification. Manipulation of these elements increases players' dedication to the game and time spent on it. In an educational context, the same elements could lead to greater student engagement. Several other authors have similarly produced instructions and recommendations for gamification, and we applied these in our educational project, described below. Merquis [14] indicates that gamification in higher education can increase students' compromise, flexibility, competition and cooperation. González and Mora [15] show the positive reception of gamification by students, and report an increase in class attendance. Sánchez-Martin et al [16] show that providing information to students about the evaluation process stimulated their greater effort in "active seminars". Herbert [17] notes that, in gamification, "it is necessary to have a structure composed of dynamics focused on challenges, rewards, achievements, etc., which helps the teacher to transform training classes into [a series of] attractive learning moments, where students improve their academic results and participate actively in class".

Among the many and varied resources that can be used, Socrative - a commercial web-based platform - achieves many of the aims of gamification in education. Narbón-Perpiña and PeiróPalomino [18], Mork [19], Frías et al. [20] and Balta and Güvercin [21] highlight the positive effects of the use of Socrative within classrooms.

Studies carried out at the University of Málaga [22], University of Valencia [23], European University of Madrid [24] and University of Alicante [25] conclude that Kahoot is also an excellent tool for learning activities and innovative teaching. It helps to achieve active student participation, as students generally view Kahoot as a game, rather than an assessment tool [26]. The use of Kahoot encourages good relations within the classroom and increases class attendance [27]. A study of the application carried out by Alf Inge Wang (a co-inventor of Kahoot) at the Norwegian University of Science and Technology (NTNU) found that students who used Kahoot learned more than students who used different game dynamics.

Valenzuela and Pérez [28] concluded that "A modern and friendly virtual platform is not a guarantee of effectiveness and quality in the teaching-learning process, because virtual environments have not been able to replace the teacher's work. However, it can be a good tool when the teacher decides to use it, because it can help to generate didactic activities that enhance face-to-face training. And in some cases it encourages more autonomous student work".

According Palomares et al. [29], the use of gamification and other active methodologies is beneficial for students, as it increases student motivation and attention, and leads to higher marks.

The main aim of this work is to evaluate the use of active methodologies, which place the students at the center of the learning process and make them the protagonists of discovery, rather than just passive information receivers, in conjunction with gamification and the "flipped classroom" teaching method. The remainder of the paper is divided into the following sections: section 2 describes the methodology used, section 3 discusses the results achieved, and section 4 presents the conclusions.

\section{METHODOLOGY}

In the 2015-2016 academic year, the Educational Innovation Project (PIE15 / 174) was launched, funded by the University of Malaga (UMA). The project consisted of the application of the "flipped classroom" pedagogical model to a selection of academic subject areas and courses at UMA, taking into account the objectives and the nature of each. The intention was to help students take responsibility for their own learning. University students are expected to be perfectly capable of being masters of their own time and effort, but the project involved "giving voice to students and allowing them to be the main actors in the class, which is gradually configured according to the same development that they require and propose" [30]. The integration of the flipped classroom into the educational process led to an increase in students' motivation and interest. It had a positive impact on their determination and autonomy, because students took responsibility for their own learning in the flipped classroom model [5]. 
In a university like UMA, with many students per classroom, it is difficult to control the progress of each student and their degree of assimilation of new subject content, so the flipped classroom can be seen as "a framework that ensures that students receive a personalized education adapted to their individual needs" [1].

As a result of the enthusiasm for and success of that initial project, more professors and subjects have been integrated into the initiative, which has materialized in a new Educational Innovation Project (PIE17 / 116), a continuation of the previous one. At present, the Faculty of Economics and Business Studies, the Faculty of Commerce and Management, and the Faculty of Sciences of the UMA and the Institute of Accounting and Administration of Porto (ISCAP) of the Polytechnic of Porto are involved in this project. It has been applied in the subjects of Accounting, Mathematics, and Crystallography and Mineralogy.

To achieve our goals we have applied ICT educational techniques such as the use of Socrative, Kahoot and other active methodologies through the Moodle platform. Socrative is an application that allows the creation of questionnaires, which can be the basis of student competition. It includes multiple choice, true/false or short answer questions. For use in the classroom, only an internet connection and a mobile phone, computer or tablet are required. There are two versions of Socrative: one is free and the other has to be paid for, but has more features than the free version. It allows student participation to be measured, and feedback can be given to students in real time. It also supports continuous evaluation, since the results of the questionnaires can be downloaded. Socrative is more flexible than other applications such as Kahoot, because there is no limitation on the number of characters in the formulation of questions. It should be noted, though, that the free version is limited to use by 50 students.

In our project, Socrative is used for two kinds of activities. Firstly, it is used as a platform in real time, where students can raise questions before and during the class, through the short answers. The teacher will then respond to any questions in the most appropriate manner. Secondly, Socrative is used to present competitive quizzes in the classroom (similar to the Trivial game). Typically, teams race to answer several questions in the classroom, by typing the answer through the tool. In this way, the teacher has a real-time assessment of student progress.

The other principal application, Kahoot!, is also available as a free version, either as an app or as a web-based resource, that allows the creation of test questionnaires for classroom assessments. It provides an immediate feedback, in the form, for example, of individual test results and student rankings ${ }^{1}$, which in itself stimulates motivation and interest. This tool permits questionnaires to be changed after feedback (for example by the addition of a time limit with a countdown, the listing of multiple-choice answers, or the inclusion of photographs or video). Therefore, gamification in the classroom has positive motivational effects [31].

In our flipped classroom project, we are using Kahoot to present activities to do in class. There are different modes of use, however. It can be used to ascertain the degree of assimilation of concepts that the student has studied autonomously, through material provided by the teacher, as well as to evaluate the level of knowledge once a lesson is finished. In the first case, the student must work through a lesson that has been made available in the Moodle platform of the Virtual Campus. Then, at the beginning the next class, the teacher might present a questionnaire through the Kahoot app to determine the degree of learning achieved by the students and to detect possible difficulties or questions that the teacher can then clarify. The results in the test (number of right/wrong answers, score) will contribute to the student's continuous assessment, so it is not only a learning technique but also an evaluation of student progress. In the second case, the teacher presents a Kahoot questionnaire when the lesson has finished, to check on students' knowledge acquisition, which again can contribute to continuous evaluation.

Moodle has been used in the project as an active learning tool as it is the online platform available in our academic institutions. It is based on free software that favours "combined learning" (b-learning, combined learning), a model that is defined as the teaching system that combines face-to-face teaching with virtual teaching. It is an idea that is actively being developed in higher education. The teacher takes on a double role, as a trainer and as a tutor, according to the particular learning environment [32]. Although there are many platforms available to institutions of higher education, the Prendes study [32], conducted in 2009, indicates that $85.1 \%$ have Moodle. This virtual platform offers

\footnotetext{
${ }^{1}$ Students take part with a nickname or ID, to facilitate the treatment of data in Excel and to allow answers to remain anonymous.
} 
the teacher and the student a wide range of tools, from individual activities such as assignments and questionnaires to collaborative ones such as chats, forums, workshops, databases, glossaries, wikis and group tasks. It allows lessons and materials to be packaged and presented in standard SCORM or IMS formats.

In our project we have used, up to now, the "task" module in Moodle, which allows, in a simple but flexible way, student work to be collected in different formats, such as exercises or solutions to practical problems. This has allowed us to evaluate work online and provide comments online, which facilitates the work of the teacher and improves communication with the student.

We have also used the Moodle "knowledge tests" as one of the key pieces in the functioning of our "flipped classroom" methodology. These tests are constructed from a question bank, previously created by a group of teachers. Two types of tests have been carried out: self-assessment tests and formal exams. The former is made available to students after each lesson, and they can do them voluntarily, working their way from basic through to advanced concepts. This allows students to assess their assimilation of the concepts of the lesson, and to review any concepts that have not been fully assimilated. The formal exams, on the other hand, contain questions on all the lessons to be evaluated and contribute to the student's final qualification.

In the project, at the end of the teaching of each subject, we distributed surveys to students to collect their opinions and record their degree of satisfaction with the model, as well as the suitability of the resources used. We also analysed the grades obtained in the different subject areas involved in the project. All these data were analysed to allow us to draw conclusions regarding the effects of the project.

\section{RESULTS}

Here, we report students' opinions on the use of Kahoot and the impact that the Moodle questionnaires have had on students' marks.

Kahoot questionnaires were used with eight teaching groups in the academic year 2017-2018. As indicated above, at the end of each course, the students were asked to evaluate the methodology through a survey. One of the questions in this survey was as follows:

What is your opinion about the use of the Kahoot application?

The response was on a Likert scale, with values between 1 and 5 , on which 1 was "Very negative" and 5 was "Very positive". The results of these surveys are shown in Table 1 and Figure 1.

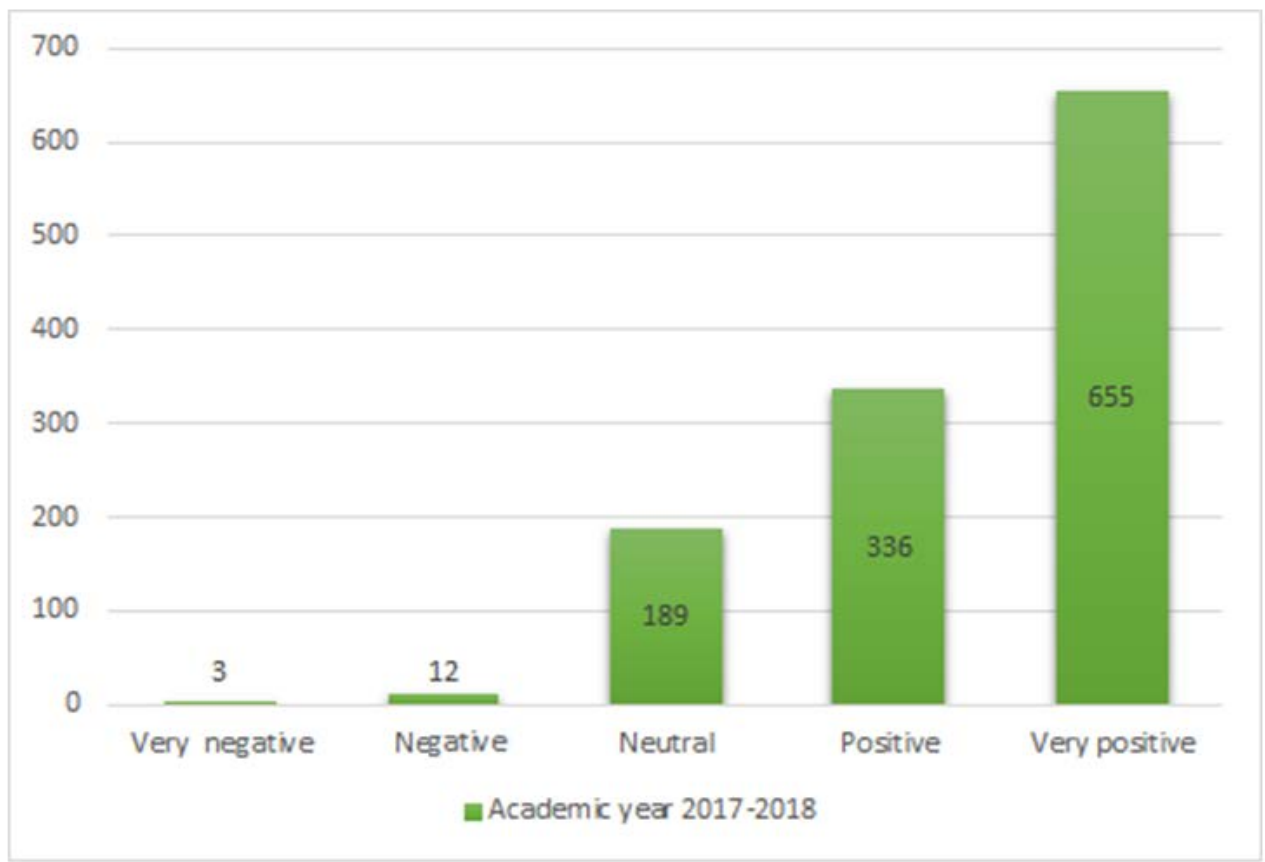

Figure 1. Students' opinion on the use of Kahoot questionnaires in the classroom (2017/2018). 
Figure 1 shows the distribution of values given in the surveys. The total number of surveys is 1,195 . The number of students who gave a 'Very negative' or 'Negative' assessment is very low (15). The most recorded opinion is 'Very positive' (655 students), followed by 'Positive' and 'Neutral'.

Table 1. Descriptive analysis of students' opinions about the use of Kahoot questionnaires in the classroom (2017/2018).

\begin{tabular}{|l|c|c|}
\cline { 2 - 3 } \multicolumn{1}{c|}{} & Number of students & $\%$ \\
\hline Very negative & 3 & $0,10 \%$ \\
\hline Negative & 12 & $0,83 \%$ \\
\hline Neutral & 189 & $6,53 \%$ \\
\hline Positive & 336 & $23,21 \%$ \\
\hline Very positive & 665 & $69,43 \%$ \\
\hline Median & \multicolumn{2}{|c}{4} \\
\hline Mode & \multicolumn{2}{|c}{5} \\
\hline
\end{tabular}

Table 1 shows the numbers and percentages of students marking each point on the Likert scale, as well as the statistical median and mode values, in academic year 2017/2018. We can see that nearly $70 \%$ of the students rated the use of Kahoot as 'Very positive', and more than $90 \%$ rated it at least 'Positive', which means that the general assessment of the students was good or very good, with an extremely low level of data dispersion. The value of the median (central position) is 4 . It is also worth highlighting that the value of the statistic modal value (value most often recorded) is 5 .

These results allow us to affirm that this tool is highly valued by the students and helps in the learning process, in a significant way.

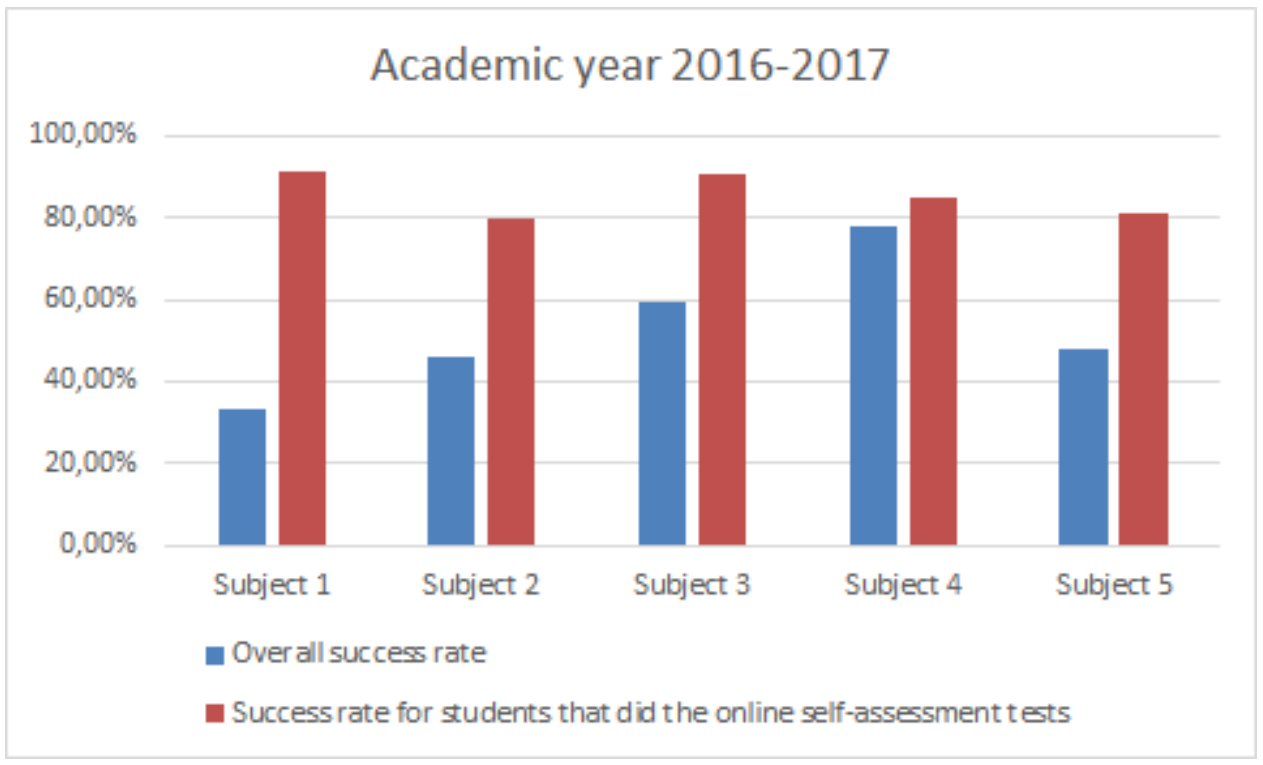

Figure 2. Success rates, academic year 2016-2017.

Moodle knowledge tests began to be used in some teaching groups in the 2016-2017 academic year and their use became widespread in 2017-2018. A student self-assessment test was made available at the end of each lesson whereby students could verify, voluntarily, their grasp of the lesson content, and evaluate their level of learning. In the 2016-2017 academic year, online self-assessment tests were offered to students taking five different subjects. Figure 2 shows the percentages of students who passed each of the five subjects both overall and among those who completed the Moodle selfassessment tests at the end of each lesson. 
In the 2017-2018 academic year, self-assessment tests for all lessons were offered in nine subjects. Figure 3 shows the percentages of students who passed each of the nine subjects, both overall and among those who completed the self-assessment tests.

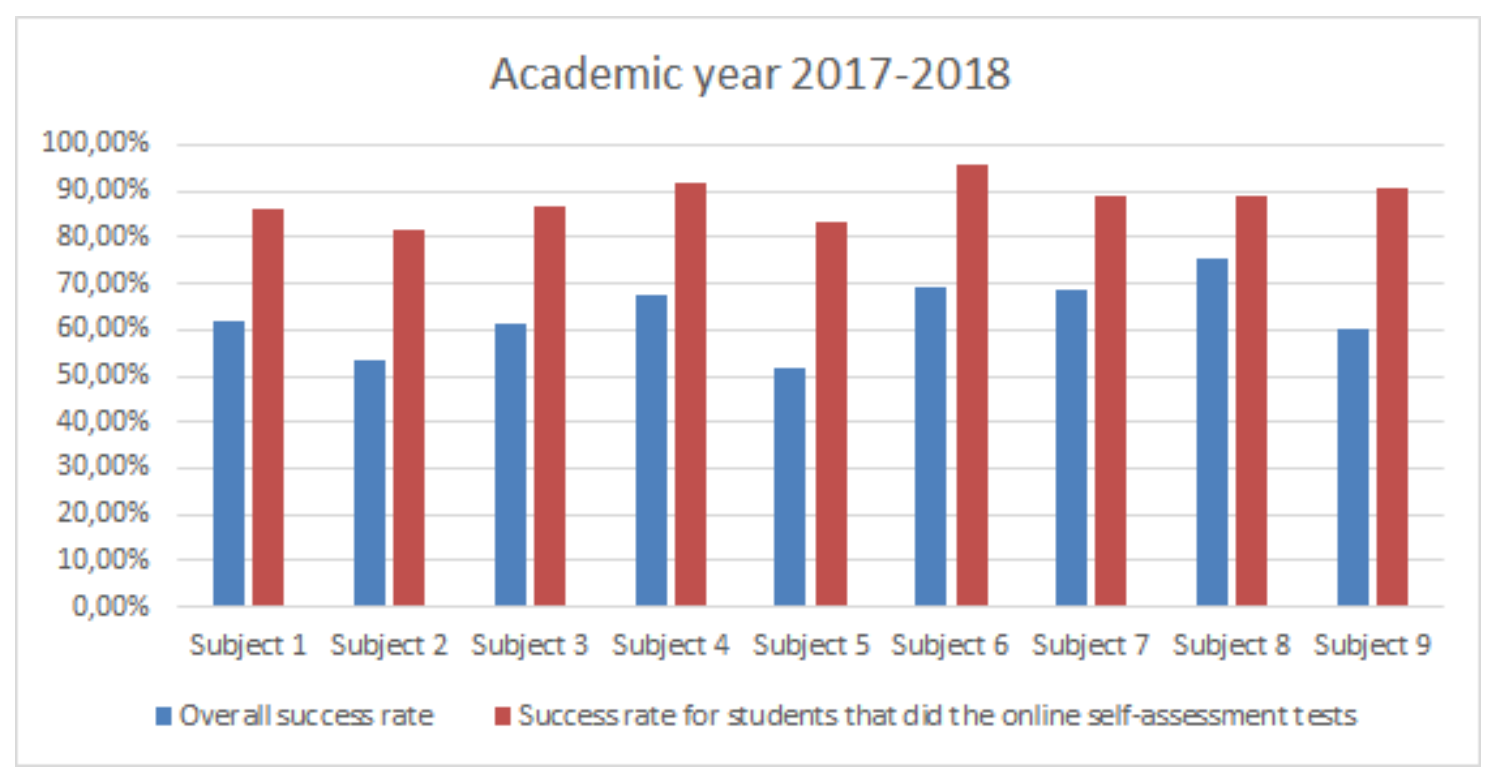

Figure 3: Success rates, academic year 2017-2018.

As can be seen from Figures 2 and 3, there is a big difference in the percentage success rates: those who completed the continuous assessment tests had much higher pass rates. Furthermore, the overall success rate improved considerably in the 2017-2018 academic year, which may be due to the application of all the project techniques in the subjects analysed, although it is true that the groups of students are not the same and, therefore, this comparison may be partially biased.

We believe that improvements in student learning were obtained by the methodological change carried out in the subjects, which made the students an active element of the teaching-learning process from the first day of teaching, and not only when taking the final evaluation tests.

\section{CONCLUSIONS}

Nowadays, education at its different levels should not be limited to transmitting the established content of any particular subject area but should integrate in the teaching-learning techniques the use of innovative digital resources. In this context, the use of gamification - the application of the attractive components of games and video games in different environments - should go beyond attempts to increase student motivation, but rather should be used to solve problems such as inactivity or dispersion, through greater student involvement.

However, the success or failure of a gamified activity is not going to relate exclusively to the tools used, but will also depend on how the gamified task is designed to increase the motivation of the student. In this sense, when students are given an opportunity to participate actively in the learning process, their interest in the subject increases, and they are more motivated to achieve the best possible results.

The results of the surveys at the end of the courses show that the students prefer this methodology to traditional classes. Also, they perceive that they learn more and better with this class dynamic. Motivation is a key factor in achieving meaningful learning and this model creates interest in active learning and generates greater student autonomy.

In terms of academic performance, we have observed throughout the courses in which we have applied this methodology an important trend towards improvement, with the caveat that comparisons have been made between different cohorts of students.

With regard to gamification, the use of Kahoot in class is highly valued by students and helps in the learning process, in a significant way. Nearly $70 \%$ of the students rated the use of this tool as 'Very positive', and more than $90 \%$ as 'Positive' or 'Very positive'. 
In the project model, Moodle is used as an active learning tool, for example in presenting students with voluntary self-assessment tests. The students are now more motivated and we can verify that the percentage of students passing the subjects, has increased.

We believe that the improvement in academic results may be due to the application of all the project techniques in the subjects analysed, although it is true that different cohorts of students are being compared, which may bias the comparison. In any case, we consider that the improvements are due to the methodological change carried out in the subjects, which make the student an active element of the teaching-learning process from the first day of teaching, and not only when taking the final evaluation tests.

\section{REFERENCES}

[1] J.Bergmann and A.Sams, Flip your classroom: Reach every student in every class every day, Washington, D.C., EEUU: International Society for Technology in Education. 2012.

[2] J. F. Strayer, "How learning in an inverted classroom influences cooperation, innovation and task orientation," Learning Environments Research, vol. 15, pp. 171-193, 2012. DOI 10.1007/s10984012-9108-4.

[3] J. L. Bishop and M. A. Verleger, "The flipped classroom: A survey of the research," in ASEE National Conference Proceedings, Atlanta, GA, pp. 1-18, 2013.

[4] J O'Flaherty and C Phillips, "The use of flipped classrooms in higher education: a scoping review", The Internet and Higher Education, vol 25, pp.85-95, 2015.DOI 10.1016/j.i.heduc.2015.02.002

[5] A.P. Lopes and F. Soares, "Perception and performance in a flipped Financial Mathematics classroom", The International Journal of Management Education, vol 16 (1), pp. 105-113, 2018. DOI 10.1016/j.jijme.2018.01.001

[6] L. Ogden and N. Shambaugh, "Best Teaching and Technology Practices for the Hybrid Flipped College Classroom," Handbook of Research on Innovative Pedagogies and Technologies for Online Learning in Higher Education, USA, pp. 281-303, 2017.

[7] S. Deterding, D. Dixon, R. Khaled, and L. Nacke, "From game design elements to gamefulness", in Proceedings of the 15th International Academic MindTrek Conference on Envisioning Future Media Environments - MindTrek '11, 2011, p. 9.

[8] M. Foncubierta y C. Rodríguez, "Didáctica de la gamificación en la clase de español, Edinumen, Retrieved from http://blog.edinumen.es/index.php/2014/12/12/didactica-de-la-gamificacion-en-laclase-de-espanol/

[9] K. M. Kapp, The gamification of learning and instruction: game-based methods and strategies for training and education. Pfeiffer, 2012.

[10] J. Hamari and J. Koivisto, "Social motivations to use gamification: an empirical study of gamifying exercise". 21st European Conference on Information Systems. Utrecht, Netherlands, June 5-8, 2013.

[11] M. D. Hanus and J. Fox, "Assessing the effects of gamification in the classroom: A longitudinal study on intrinsic motivation, social comparison, satisfaction, effort, and academic performance," Comput. Educ., vol. 80, pp. 152-161, 2015. DOI 10.1016/j.compedu.2014.08.019.

[12] M. Prensky, "Digital Game-Based Learning," ACM Comput. Entertain., vol. 1, no. 1, 2003.

[13] G. Zichermann y C. Cunningham,. "Gamification by Design: Implementing Game Mechanics in Web and Mobile Apps". Cambridge, O'Reilly Media, 2011.

[14] J. Marquis: "5 Easy Steps to Gamifying Higher Education". Retrieved from http://classroomaid.com/2013/08/16/ 5-easy-steps-to-gamifying-highereed/

[15] C.González y A.Mora, "Técnicas de Gamificación aplicadas en la docencia de Ingeniería Informática", Revisión, vol 8, n¹, 29-40, 2015.

[16] M.Sánchez-Martín, et al "Estudiantes mejor informados: mejores resultados académicos". Revista de Contabilidad - Spanish Accounting Review, 2016.DOI 10.1016/j.rcsar.2016.03.001. 
[17] O. Herbert Alexander, "La gamificación como estrategia metodológica en el contexto educativo universitario". Realidad y Reflexión, № 44, julio- diciembre, pp. 29-47, 2016.ISSN 1992-6510.

[18] I. Narbón-Perpiña y J. Peiró-Palomino, "La plataforma Socrative como herramienta de aprendizaje: Una aplicación a la asignatura métodos cuantitativos". Revista electrónica sobre la enseñanza de la Economía Pública, № 2, pp. 41-50, 2018. (https://e-publica.unizar.es/es/articulo/ la-plataforma-socrative-herramienta-aprendizaje-una-aplicacion-la-asignatura-metodoscuantitativos)

[19] C.M. Mork, "Benefits of using online student response systems in Japanese EFL classrooms", The Jalt Call Journal, vol. 10 (2), pp. 127-13, 2014.

[20] M. V. Frías, C. Arce y P. Flores-Morales, "Uso de la plataforma socrative.com para alumnos de Química General”, Educación Química, vol. 27, pp. 59-66, 2016.

[21] N. Balta y S. Güvercin, 'Increasing undergraduate students' exam performances in statistics course using software Socrative", The Turkish Online Journal of Educational Technology - Special Issue for IETC, ITEC, IDEC, ITICAM, pp. 314-321, 2016.

[22] J. Benítez, O. Romero, E Fernández, R Merino y I López, "Gamificación en Educación Física: efecto de la metodología M-Learning en la asimilación de contenidos". Congreso Mundial de Educación. EDUCA, Santiago de Compostela, 2019.

[23] A. Fuertes, M. García, M.A. Castaño, E. López, M. Zacares, M Cobos, R. Ferris and F. Grimaldo, "Uso de herramientas de respuesta de audiencia en la docencia presencial universitaria. Un primer contacto". Actas de las XXII Jenui. Almería, 6-8 de julio, 2016. http://goo.gl/iicxRq

[24] E. Pintor, P. Gargantilla, B. Herreros and M. López, "El aprendizaje basado en juegos: experiencias docentes en la aplicación de la plataforma virtual Kahoot, .XI Jornadas Internacionales de Innovación Universitaria. Educar para transformar, 2014. http://goo.gl//4ICvA

[25] M.M Moya, M Carrasco, M.A. Jiménez, M.A, A. Ramón,C Soler and M.T. Vaello, "El aprendizaje basado en juegos: experiencias docentes en la aplicación de la plataforma virtual Kahoot". Actas XIV Jornadas de Redes de Investigación en Docencia Universitaria. Alicante, 30 de junio y 1 de julio, 2016. http://goo.gl/V10iVk

[26] A. Fernández, J. Olmos, J and J. Alegre, "Valor pedagógico del repositorio común de conocimientos para cursos de dirección de empresas", Revista d'innovació Educativa, 16, 2016. DOI 10.7203/attic.16.8044

[27] G. Del Cerro, "Aprender jugando, resolviendo: diseñando experiencias positivas de aprendizaje", XII Jornadas Internacionales de Innovación Universitaria Educar para transformar: Aprendizaje experiencia, 2015. https://goo.gl/x6Z70t

[28] B. Valenzuela Zambrano y M.V. Pérez Villalobos "Aprendizaje autoregulado a través de la plataforma virtual Moodle" Educ.Educ.Vol.16, No. 1, 2013, pp. 66-79

[29] A. Palomares Ruiz, R. García Perales and A. Cebrián Martínez, "Integración de herramientas TIC de la Web 2.0 en Sistemas de Administración de Cursos (LMS) tipo Moodle", Incluido en: "Investigación en docencia universitaria. Diseñando el futuro a partir de la innovación educativa, pp. 980-990. Ed. Octaedro, S.L. Barcelona, 2017.

[30] A. García-Barrera, "El aula inversa: cambiando la respuesta a las necesidades de los estudiantes". Avances en Supervisión Educativa. Revista de la Asociación de Inspectores de Educación de España, vol. 19, pp. 1-8, 2013.

[31] Hamari, J.; Koivisto, J.; Sarsa. H., Does Gamification Work? - A Literature Review of Empirical Studies on Gamification, 47th Hawaii International Conference on System Science, 2014. https://goo.gl/FmkgX0

[32] M.P. Prendes, "Plataformas de campus virtual con herramientas de software libre: Análisis comparativo de la situación actual en las universidades españolas". (http://www.um.es/ campusvirtuales/informe_final_CVSL_SF.pdf) 